\title{
First case of late parental infanticide in birds.
}

\section{Primer caso de infanticidio parental tardío en aves.}

\author{
Aitor Galarza ${ }^{1 *}$, Xarles Cepeda ${ }^{1}$
}

\begin{abstract}
The first case of late parental infanticide in birds is reported. On June 29, 2017, an adult white stork attacked and threw one of the nestlings out of the nest when it was around 53 days old. It is suggested that the death of one parent may have been the cause of this late brood reduction.
\end{abstract}

Key words: Urdaibai, White stork, Ciconia ciconia, brood reduction.

\section{Resumen}

Se notifica el primer caso de infanticidio parental tardío registrado en aves. El 29 de junio de 2017 una cigüeña blanca adulta ataca hasta arrojarlo del nido a uno de sus pollos cuando éste tenía alrededor de 53 días de edad. Se sugiere que la muerte de uno de los progenitores podría ser la causa de esta reducción tardía de la nidada.

Palabras clave: Urdaibai, Cigüeña blanca, Ciconia ciconia, reducción de nidada.

\section{Laburpena}

Hegaztien arteko gurasoen infantizidio berantiarraren lehenengo kasua azaltzen da. 2017ko ekainaren 29an, zikoina zuri heldu batek eraso egin zion 53 egun inguru zituen bere txito bati, habiatik bota zuen arte. Kumaldi murrizketa berantiar honen zergatia guraso baten heriotza izan daitekeela iradokitzen da.

Gako hitzak: Urdaibai, Zikoina zuria, Ciconia ciconia, kumaldi murrizketa.

1 Urdaibai Bird Center, Sociedad de Ciencias Aranzadi

Orueta 7, 48314 Gautegiz-Arteaga

*Correspondencia: aitorgalarzai@gmail.com 
Infanticide, defined as the killing of young individuals by a conspecific adult, is a rarely reported behaviour in the ornithological literature (Veiga, 2000; Zielinski, 2002, Moreno, 2012). Avian infanticide can be committed by non-genetic or by genetic parents (parental infanticide). In the first case, new breeding partners of widowed individuals or unmated individuals commit infanticide to increase their chances of a breeding attempt or to improve reproductive success (Fujioka, 1986; Moller, 1988; Veiga, 1990; Pinxten et al., 1995). In the case of parental infanticide, the most plausible motive of killing nestlings is related with the difficulty of raising the current brood due to resource scarcity (Tortosa \& Redondo, 1992; Mock \& Parker, 1997). However other motives have been suggested, such as a response to stress, cuckoldry or intraspecific brood parasitism (Coon et al., 2018). Evidences of avian parental infanticide have been reported in coots (Horsfall 1984), gulls (Urrutia \& Drummond, 1990), spoonbills (Aguilera, 1990), storks (Tortosa \& Redondo, 1992; Zielinski, 2002), ground cuckoos (Ohmart, 1973) and passerines (Long, 1966; Pinowski, 1968; Moller, 1988; Chamberlain-Auger et al., 1990; Harris et al., 2016; Coon et al., 2018).

The white stork Ciconia ciconia (L. 1758) is a monogamous species, which usually has clutches of 4 eggs (range (1-7) laid at intervals of 1-4 days (Cramp \& Simmons, 1977). Because incubation starts with the second egg, hatching is asynchronous so that there can be an age difference of almost ten days between the oldest and the youngest nestling (Zielinski, 2002). Both parents feed the nestlings, which fledge at 58-64 days and become independent a few days later (Del Hoyo et al., 1992). If there is a food shortage, nestlings may die of starvation and also due to infanticide of the youngest sibling, which usually occurs when they are one week old (Tortosa \& Redondo, 1992).

In the present note, we describe the first case of late parental infanticide in birds, which was committed by a white stork and occurred at the Urdaibai Biosphere Reserve (Basque Country, North Spain) on 29th June 2017. Between 2003 and 2008 a white stork reintroduction project was developed in this reserve (Galarza \& García, 2012) and by 2017 two pairs were breeding there. Their nests were at a distance of $1.7 \mathrm{~km}$ from each other. The white stork nest of this note was situated on a platform installed in a Monterey pine Pinus radiata D.Don, $1.1 \mathrm{~km}$ away from the observatory from which the event was recorded. Neither member of the pair was ringed. The pair started incubation on approximately April 4. On $15^{\text {th }}$ May three small nestlings were observed. These nestlings were weighted and ringed on $19^{\text {th }}$ June. Ten days later, when the nestlings were approximately 53 days old, one of the adults was videorecorded pecking one of the nestlings on the head. It was the nestling of intermediate weight. Finally, the adult threw the nestling out of the nest (https://youtu.be/MFvQiHggShY). The nestling was collected and taken to the Biscay Wildlife Recovery Centre (Biscay County Council) where it died. On arrival at the Centre it weighed $2.9 \mathrm{~kg}$. Autopsy revealed a fracture to the sinuses and another between the atlas and the skull. No infection by external parasites was observed. In the video recording, it can 
be observed that the victimized nestling had the plumage of a fully-grown bird and was of a similar size to the infanticidal adult.

A case of parental infanticide affecting a fully developed nestling had not been described until now. It is difficult to explain what the adaptive advantage of reducing brood size would be once a nestling is close to becoming independent. A plausible hypothesis is that the unexpected loss of one parent would have forced the widowed one to kill one nestling in order to guarantee the survival of the rest of the brood. Because neither of the adults were ringed, this hypothesis was difficult to prove. However, there is evidence that would support this hypothesis as only one adult was observed from the day of infanticide to the day surviving nestlings left the nest.

\section{Acknowledgements}

Jose Miguel Escribano (Biscay Wildlife Recovery Centre) informed on the victimized stork body condition, an anonymous referee improved an earlier version of the note, and Rowan Hardman made corrections to English.

\section{Bibliography}

Aguilera, E., 1990. Parental infanticide by White Spoonbills Platalea leucorodia. Ibis 132, 124-125.

Coon, J.J., Nelson, S.B., West, A.C., Bradley, I.A., Miller, J.R., 2018. An observation of parental infanticide in Dickcissels (Spiza americana): video evidence and potential mechanisms. The Wilson Journal of Ornithology 130(1), 341-345.

Chamberlain-Auger, J.A., Auger, P.J., Strauss, E.G. 1990. Breeding biology of American crows. Wilson Bull. 102(4), 615-622.

Cramp, S., Simmons, K.E.L. (eds.), 1977. The Birds of Western Paleartic. Vol 1. Oxford University Press, Oxford.

Del Hoyo, J., Elliot, A., Sargatal, J., 1992. Handbook of the Birds of the World. Vol. 1. Lynx Edicions, Barcelona.

Fujioka, M., 1986. Infanticide by a male parent and by a new females mate in colonial egrets. Auk 103(3), 619-621.

Galarza, A., García, I., 2012. Restocking white stork population Ciconia ciconia (L., 1758) in Biscay: reintroduction in the Urdaibai Biosphere Reserve. Munibe, Cienc. nat 60, 191-200. 
Harris, S.N., Wagner, L.M., Miller, K.E., 2016. Infanticide in a Florida Grasshopper sparrow (Ammodramus savannarum floridanus). The Wilson Journal of Ornithology 128(4), 918920.

Horsfall, J., 1984. Brood reduction and brood division in coots. Anim. Behav. 32(1), $216-$ 225.

Long, C., 1966. House sparrow carrying live nestling. British Birds 59, 114-115.

Mock, D.W., Parker, G.A., 1997. The evolution of sibling rivalry. Oxford Univ. Press.

Moller, A.P., 1988. Infanticidal and anti-infanticidal strategies in the swallow Hirundo rustica. Behavioral Ecology and Sociobiology 22, 365-371.

Moreno, J., 2012. Parental infanticide in birds through early eviction from the nest: rare or under-reported? Journal of Avian Biology 43(1), 43-49.

Pinowski, J., 1968 Fecundity, mortality, numbers and biomass dynamics of a population of the tree sparrow (Passer m. montanus). Ekol. Pol. Ser. A 16, 1-58.

Pinxten, R., Eens, M., Verheyen, R.F., 1995. Response of male European starlings to experimental removal of their mate during different stages of the breeding cycle. Behaviour 132(3-4), 301-317.

Tortosa, F.S., Redondo, T., 1992. Motives for parental infanticide in White storks Ciconia ciconia. Ornis Scandinavica 23(2), 185-189.

Urrutia, L.P., Drummond, H., 1990. Brood reduction and parental infanticide in Heermann's gull. Auk 107(4), 772-774.

Veiga, J.P., 1990. Infanticide by male and female house sparrows. Anim. Behav. 39(3), 496502 .

Veiga, J.P., 2000. Infanticide by male birds. In: Schaik, C.P. Van, Janson, C.H. (eds.), Infanticide by males and its implications, 198-220. Cambridge University Press.

Zielinski, P., 2002. Brood reduction and parental infanticide. Are the White stork Ciconia ciconia and the Black stork C.nigra excepcional? Acta Ornithol. 37(2), 113-119.

Fecha de recepcion/Date of reception: 20/05/2020

Fecha de aceptacion/Date of acceptance: 16/07/2020

Editor Asociado/Associate editor: Iván de la Hera 